\title{
$\beta 1$-Adrenoceptor-Mediated Amylase Release and Cyclic AMP Accumulation in Rat Parotid Gland Tissue
}

\author{
Yuko SUZUKI and Hideyo OHSHIKA \\ Department of Pharmacology, Sapporo Medical College, Sapporo 060, Japan
}

Accepted December 3, 1984

\begin{abstract}
The present study was carried out to determine the relationship of $\beta_{1}$ and $\beta_{2}$-subtype to amylase release and cyclic AMP (CAMP) accumulation in rat parotid tissue. In in vitro experiments, $\beta$-adrenergic agents (isoproterenol and dobutamine)-induced amylase release and CAMP accumulation were all completely inhibited by the $\beta_{1}$-antagonist metoprolol, but incompletely inhibited by the $\beta_{2}$ antagonist butoxamine. The $\beta_{2}$-agonist procaterol caused little or no amylase release or CAMP accumulation. Our results suggest that both amylase release and cAMP accumulation in rat parotid tissue may be selectively induced by $\beta_{1}$ adrenergic stimulation.
\end{abstract}

It has been generally accepted that the $\beta$-adrenergic signal for amylase release in rat parotid gland is mainly given via $\beta_{1}$ subtype adrenoceptors $(1,2)$ and that cyclic AMP (cAMP) plays a major role as a second messenger in the regulation of the amylase release by $\beta$-adrenergic agonists (3). However, the development of many new $\beta$ adrenergic agonists and antagonists has brought about some confusion concerning the functions of $\beta$-subtype adrenoceptors. For instance, Carlsöö et al. (4) have recently reported, in a study using some relatively selective $\beta$-adrenergic agents, that amylase release and CAMP accumulation may be separately induced by stimulation of $\beta_{1}$ - and $\beta_{2}$-adrenoceptors. As it has been thought to be necessary to ascertain the subtypes of $\beta$ adrenoceptors related to these two $\beta$ adrenergic responses, the present study was carried out to determine whether $\beta_{1}$ - or $\beta_{2}$ adrenergic receptors are responsible for amylase release and CAMP accumulation in rat parotid gland. To accomplish this, several types of $\beta$-agonists and antagonists were used.

Male Wistar rats, weighing 180-240 g, were used and deprived of food for $16 \mathrm{hr}$ prior to each experiment. Preparation and incubation of parotid slices were carried out by the procedure described previously (5).
Parotid glands were removed from rats under pentobarbital sodium $(50 \mathrm{mg} / \mathrm{kg}$ ) anesthesia. Pieces of parotid tissue were incubated in $5 \mathrm{ml}$ of Krebs-Ringer-Tris buffer ( $\mathrm{pH} 7.4$ ) bubbled with pure oxygen at $37^{\circ} \mathrm{C}$ (5). After a 25 -min preincubation, the slices were incubated with or without drugs in buffer for $30 \mathrm{~min}$. At the end of the incubation, the slices were transferred and then homogenized in another buffer. Amylase activity in the media and the homogenate was measured by the method of Bernfeld (6). The amount of released enzyme was expressed as a percent of the total content of the enzyme which was initially contained in the slices.

For measurement of cAMP content in the tissue, parotid slices were incubated for $5 \mathrm{~min}$ with or without drugs, and after incubation, the slices were rapidly transferred into liquid nitrogen. Cyclic AMP was measured by radioimmunoassay using a commercial assay kit (Yamasa Shoyu). The results are expressed as the ratio of the value in the presence of drugs to the basal value.

Protein concentration of the tissue was measured by the method of Lowry et al. (7).

Levels of significance were calculated using Student's $t$-test.

The following drugs were used: (-)isoproterenol (+)-bitartrate (Sigma), procaterol hydrochloride (Otsuka), dobutamine 
hydrochloride (Shionogi), metoprolol tartrate (Fujisawa) and butoxamine hydrochloride (Burrough Wellcome Co.).

The effects of various $\beta$-agonists and antagonists on the levels of CAMP in parotid tissue are shown in Fig. 1. Cyclic AMP concentration in the tissue was elevated to about 70-fold of the basal level ( $5.7 \pm 0.55$ $\mathrm{pmol} / \mathrm{mg}$ protein) in a 5 -min incubation with isoproterenol (ISP, 10 $\left.10^{-5} \mathrm{M}\right)$. Metoprolol $\left(10^{-4} \mathrm{M}\right)$, a $\beta_{1}$-antagonist (8), completely inhibited the elevation of CAMP level induced by ISP. whereas butoxamine $\left(10^{-4} \mathrm{M}\right)$, a $\beta_{2}$-antagonist (9), was not much more effective than metoprolol. A significant increase in CAMP level (2.7-fold of the basal level) was caused by the $\beta_{1}$-agonist dobutamine (10), and this increase was completely blocked by metoprolol. However. a $\beta_{2}$-agonist (11), procaterol $\left(10^{-5} \mathrm{M}\right)$, had no effect on the CAMP level in the tissue, even with a higher dose $\left(10^{-3} \mathrm{M}\right.$, data not shown).

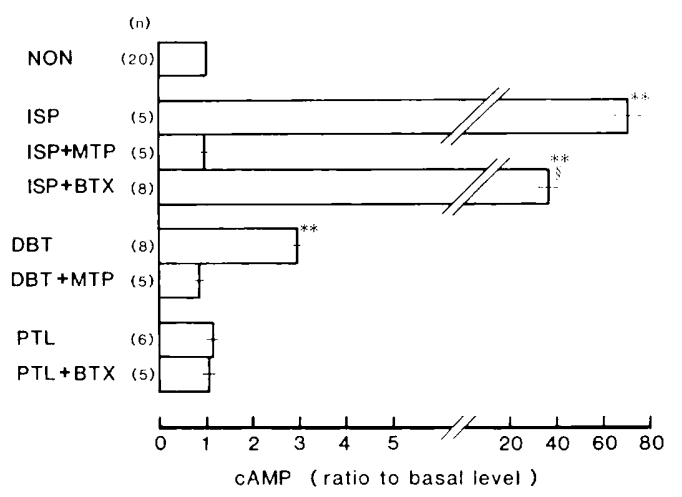

Fig. 1. Effect of $\beta$-agonists and antagonists on cyclic AMP levels in rat parotid tissues. The tissues were incubated with agonists, isoproterenol (ISP. $\left.10^{-5} \mathrm{M}\right)$, dobutamine (DBT, $10^{-5} \mathrm{M}$ ) and procaterol (PTL, $10^{-5} \mathrm{M}$ ) in $37^{\circ} \mathrm{C}$ Krebs-Ringer-Tris buffer $(\mathrm{pH} 7.4)$ for $5 \mathrm{~min}$. The antagonists, metoprolol (MTP. $10^{-4} \mathrm{M}$ ) and butoxamine (BTX, $10^{-4} \mathrm{M}$ ) were added to the medium $2 \mathrm{~min}$ before the agonists. Each column shows the ratio of the value in the presence of drugs to the basal values (unchallenged) and indicates the mean \pm S.E. The basal cAMP content is $5.7 \pm 0.55 \mathrm{pmol} / \mathrm{mg}$ protein. $\mathrm{n}$ : The number of experiments. ${ }^{*} \mathrm{P}<0.01$ for the difference from the control (unchallenged) value. $\S \mathrm{P}<0.01$ for difference from the value of ISP stimulation.
Figure 2 shows the effects of various $\beta$ agonists and antagonists on amylase release in parotid tissue. More than $40 \%$ of the total amylase was released by ISP $\left(10^{-5} \mathrm{M}\right)$ during a 30-min incubation. Metoprolol $\left(10^{-4} \mathrm{M}\right)$ clearly inhibited amylase release induced by ISP, whereas butoxamine $\left(10^{-4}\right.$ $M)$ only slightly inhibited the effect of ISP. The enzyme secretion was markedly increased by dobutamine $\left(10^{-5} \mathrm{M}, 38.4 \pm 2.4 \%\right)$, and metoprolol completely inhibited this effect. On the other hand, procaterol was much less effective on the enzyme secretion $(9.6 \pm 1.3 \%)$, and butoxamine had no effect on release induced by procaterol. Throughout the present experiments, neither metoprolol $\left(10^{-4}\right.$ $\mathrm{M})$ nor butoxamine $\left(10^{-4} \mathrm{M}\right)$ had any effect on the basal amylase release or cAMP level in the tissue.

The present results show that both amylase release and CAMP accumulaton are induced by $\beta_{1}$-type agonists. In addition, the results in experiments using $\beta_{1}$ - and $\beta_{2}$-type antagonists are compatible with the above findings. However, there is a discrepancy

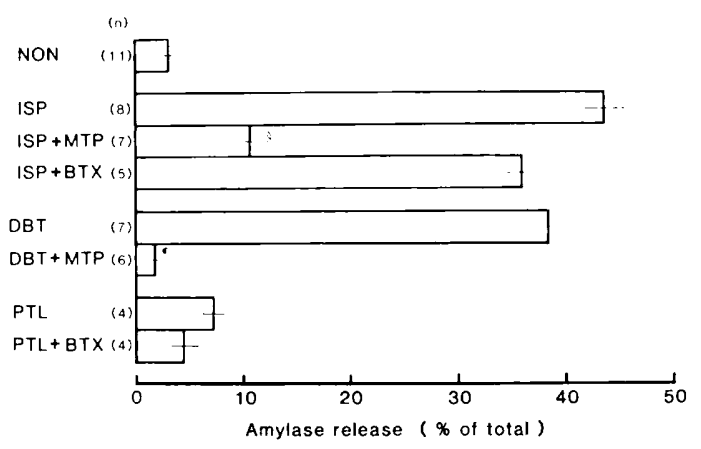

Fig. 2. Effect of $\beta$-agonists and antagonists on amylase release from rat parotid tissues. The agonists isoproterenol (ISP, $10^{-5} \mathrm{M}$ ), dobutamine (DBT, $\left.10^{-5} \mathrm{M}\right)$ and procaterol (PTL, $10^{-5} \mathrm{M}$ ) were incubated with the tissues for $30 \mathrm{~min}$ in $37^{\circ} \mathrm{C}$ KrebsRinger-Tris buffer ( $\mathrm{pH}$ 7.4) and the antagonists metoprolol (MTP, $10^{-4} \mathrm{M}$ ) and butoxamine (BTX. $\left.10^{-4} \mathrm{M}\right)$ were added to the medium $2 \mathrm{~min}$ before the agonists. Each column shows the percentage of released amylase in the tissue before incubation and indicates the mean \pm S.E. $n$ : The number of experiments. $\S P<0.01$ for the difference from the value of ISP stimulation, IP $<0.01$ for the difference from the value of DBT stimulation. 
between our results and those of Carlsöö et al. (4) on the subtype of $\beta$-adrenoceptors related to CAMP accumulation in the parotid tissue. Based on their results from experiments using terbutaline as a $\beta_{2}$-agonist, they argue that CAMP accumulation induced by $\beta$-agonists is mediated via $\beta_{2}$-type adrenoceptors. Despite the fact that terbutaline is classified as a $\beta_{2}$-agonist, it induces the accumulation of CAMP in a dose-dependent manner, just as dobutamine (a $\beta_{1}$-agonist), and it causes marked amylase release (Y. Suzuki and H. Ohshika, unpublished data). However, procaterol (a $\beta_{2}$-agonist) did not cause elevation of the CAMP level in parotid gland even with a high dose $\left(10^{-3} \mathrm{M}\right)$. It is possible that terbutaline has a $\beta_{1}$-adrenergic action together with the primary $\beta_{2}$ adrenergic action in rat parotid gland. Our results show that both amylase release and CAMP accumulation are induced by a common $\beta_{1}$-adrenergic stimulation, and these results are compatible with the concept that CAMP is a second messenger in $\beta$ adrenergic-stimulated amylase release. Amylase release induced by $\beta$-adrenergic stimulation may be dependent on the $\beta_{1}$ adrenergic stimulation of the CAMP accumulation. The effect of dibutyryl cyclic AMP on the enzyme secretion supports this hypothesis. The $\beta$-adrenoceptors in rat parotid gland may nearly all be classified into the $\beta_{1}$-subtype because of the identical potency order of $\beta$-adrenergic agonists on adenylate cyclase activation, CAMP accumulation and amylase release (1), and by the specific radioligand binding $(12,13)$. The present results suggest that the release of amylase is induced by the increase of the parotid CAMP that is caused by stimulation of $\beta_{1}$-subtype adrenoceptors in the tissue.

Acknowledgment: We wish to thank Shionogi Pharmaceutical Co., Fujisawa Pharmaceutical Co., Ostuka Pharmaceutical Co., and Burrough Wellcome Co. (U.S.A) for kindly supplying dobutamine hydrochloride, metoprolol tartrate, procaterol hydrochloride, and butoxamine hydrochloride, respectively.

\section{References}

1 Butcher, F.R., Goldman, J.A. and Nemerovski,
M.: Effect of adrenergic agents on $\alpha$-amylase release and adenosine $3^{\prime}, 5^{\prime}$-monophosphate accumulation in rat parotid tissue slices. Biochim. Biophys. Acta 392, 82-94 (1975)

2 Asking, B., Delfs, U., Emmelin, N. and Gjorstrup, P.: Amylase secretion from rat parotid glands as dependent on co-operation between sympathetic and parasympathetic nerves. Experimentia 35, 1336-1337 (1979)

3 Butcher, F.R. and Putney, J.W., Jr.: Regulation of parotid gland function by cyclic nucleotides and calcium. Adv. Cyclic Nucleotide Res. 13, 215$249(1980)$

4 Carlsöö, B., Danielsson, Å., Henriksson, R. and Idahl, L.A.: Dissociation of $\beta$-adrenoceptorinduced effects on amylase secretion and cyclic adenosine $3^{\prime}, 5^{\prime}$-monophosphate accumulation. Br. J. Pharmacol. 75, 633-638 (1982)

5 Ohshika, H., Takemura, H., Suzuki, Y., Katakura M. and Tanaka, M.: Effects of repeated exposure to isoproterenol in vivo and in vitro on amylase release from rat parotid tissue. Japan. J. Pharmacol. 34, 183-189 (1984)

6 Bernfeld, P.: Amylase, $\alpha$ and $\beta$. Methods Enzymol. 1, 149-158 (1955)

7 Lowry, O.H., Rosebrough, N.J., Farr, A.L. and Randall, R.J.: Protein measurement with the Folin phenol reagent. J. Biol. Chem. 193, 265275 (1951)

8 Åblad, B., Brog, K.O., Carlsson, E., Ek, L., Johnsson, G., Malmfors, T. and Regärdh, C.G.: A survey of the pharmacological properties of metoprolol in animals and man. Acta Pharmacol. Toxicol. 36, Supp. V, 7-23 (1975)

9 Daly, M.J., Flook, J.J. and Levy, G.P.: The selectivity of $\beta$-adrenoceptor antagonists on cardiovascular and bronchodilator responses to isoprenaline in the anaesthetized dog. Br. J. Pharmacol. 53, 173-181 (1975)

10 Tuttle, R.R. and Mills, J.: Developement of a new catecholamine to selectively increase cardiac contractility. Circ. Res. 36, 185-196 (1975)

11 Yabuuchi, Y.: The $\beta$-adrenoceptor stimulant properties of OPC-2009 on guinea pig isolated tracheai, right atrial and left atrial preparations. Br. J. Pharmacol. 61, 513-521 (1977)

$12 \mathrm{Au}$, D.K., Malbon, C.C. and Butcher, F.R.: Identification and characterization of betaadrenergic receptors in rat parotid membranes. Biochim. Biophys. Acta 500, 361-371 (1977)

13 Pointon, S.E. and Banerjee, S.P.: Alpha- and beta-adrenergic receptor of the rat salivary aland. Biochim. Biophys. Acta 584, 231-241 (1979) 